Disclosure of Interests: Belén Atienza-Mateo: None declared, José Luis Martín-Varillas: None declared, J. Loricera: None declared, Vanesa CalvoRío: None declared, Jenaro Graña: None declared, Gerard Espinosa: None declared, Clara Moriano: None declared, Trinidad Pérez-Sandoval: None declared, Manuel Martín-Martínez: None declared, Elvira Diez Alvarez: None declared, María Dolores García-Armario: None declared, Esperanza Martínez: None declared, Ivan Castellví Consultant for: I received fees less than 5000USD as a consultant for Kern and Actelion, Paid instructor for: I received fees less than 2000USD as a instructor for Boehringer -Ingelheim, Novartis and Gebro, Speakers bureau: ND, Patricia Moya: None declared, Francisca Sivera: None declared, Jaime Calvo Consultant for: Bristol-Myers Squibb, Janssen, Celgene, Sanofi Genzyme, Speakers bureau: Bristol-Myers Squibb, Isabel de la Morena Speakers bureau: Abbvie, Celgene, Pfzier, UCB, Ghebro, Roche, Sanofi, Janssen., Francisco Ortiz-Sanjuán: None declared, José Andrés Román-Ivorra: None declared, Ana Pérez Gómez: None declared, Sergi Heredia: None declared, Alejandro Olive: None declared, Águeda Prior-Español: None declared, Carolina Díez: None declared, Juanjo J Alegre-Sancho: None declared, D Ybáñez-García: None declared, Ángels Martínez-Ferrer: None declared, J. Narváez Consultant for: Bristol-Myers Squibb, Ignasi Figueras: None declared, Ana Isabel Turrión : None declared, Susana RomeroYuste: None declared, Pilar Trénor: None declared, Soledad Ojeda Grant/ research support from: AMGEN, Speakers bureau: AMGEN, Santos Castañeda Consultant for: Amgen, BMS, Pfizer, Lilly, MSD, Roche, Sanofi, UCB, D. Prieto-Peña: None declared, Monica Calderón-Goercke: None declared, Lara Sánchez Bilbao: None declared, Iñigo González-Mazón: None declared, Miguel Á. González-Gay: None declared, Ricardo Blanco Grant/research support from: Abbvie, MSD and Roche, Consultant for: Abbvie, Pfizer, Roche, Bristol-Myers, Janssen and MSD, Speakers bureau: Abbvie, Pfizer, Roche, Bristol-Myers, Janssen and MSDDOI: 10.1136/annrheumdis-2019-eular.5965

\section{FRI0271 USE OF CONTRAST ENHANCED ULTRASOUND SONOGRAPHY (CEUS) IN LARGE VESSEL VASCULITIS (LVV)}

Raoul Bergner, Jan Splitthoff, Daniel Wadsack. Klinikum Ludwigshafen, Medizinische Klinik A - Sektion Rheumatologie, Ludwigshafen, Germany

Background: C-reactive protein (CRP) and erythrocyte sedimentation rate (ESR) are important parameters in the monitoring of LVV. Since Tocilizumab is approved for treatment of LVV these cheap and easy repeatable parameters are worthless because of their normalisation by Tocilizumab. $\mathrm{MRI}$ and PET-CT as an alternative are not only much more expensive, they are also not arbitrarily repeatable and available. Thus, monitoring of LVV-Patients undergoing a Tocilizumab therapy remains unclear - especially upon showing a persisting thickened vessel wall.

Objectives: CEUS can increase the visibility of tissue perfusion, particularly if there is a very slow bloodflow, which cannot be detected by (power)-doppler sonography.

Methods: In this proof of concept study we investigated patients with active and inactive LVV (aLVV/iLVV) with CEUS. After injection of ultrasound contrast agent we measured the contrasted area of large vessels in a transverse section first if the lumen was completely contrasted and once again 4-8 seconds later. If the vessel wall incorporated the contrast agent the contrasted area increased (Fig 1). The increase of the contrasted area (CA) was correlated with CRP and ESR. Patients were only included if they were not treated with Tocilizumab and therefore ESR and CRP were usable to evaluate the disease activity.

Results: Investigated were 16 patients (13 female, 3 male), 8 with aLVV and 8 with iLVV, respectively. The mean CRP was $85 \pm 69$ (aLVV) vs. 4 $\pm 2 \mathrm{mg} / \mathrm{l}$ (iLVV) $(\mathrm{p}<0.0001)$, the ESR $80 \pm 28$ (aLVV) vs. $7 \pm 4$ (iLVV) $\mathrm{mm} / \mathrm{h}$ $(p<0.0001)$. The mean age was $74.6 \pm 8.4$ y (range $56-82$ ). The increase of the CA was $66.6 \pm 44.6$ (aLVV) vs. $2.4 \pm 6.6 \%$ (iLVV) $(p<0.0001)$. The increase correlated significantly with the CRP $r=0.87, p<0.0001$. An increase of CA of $\geq 20 \%$ has a sensitivity of $92,3 \%$ and a specificity of $90 \%$ for active LVV.

Conclusion: The results of our proof of concept study demonstrate, that CEUS can detect aLVV with a good sensitivity and specificity. Including CEUS in clinical routine will be much easier repeatable, save, quicker and by far more cost-effective then MRI or PET-CT. CEUS might be a good method for monitoring disease activity in LVV treated with Tocilizumab. The limitation of our study is the small number of patients, the missing blinding of the investigator and the method intrinsic fact, that you can't investigate all involved vessels by ultrasound/CEUS.

\section{REFERENCES}

None

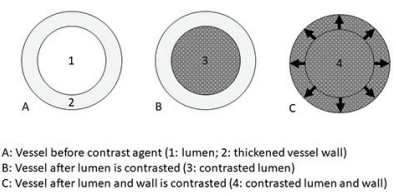

Fig.1

Disclosure of Interests: Raoul Bergner Speakers bureau: Abbvie, Roche, Novartis, Bristol Myers Squibb, Jan Splitthoff: None declared, Daniel Wadsack Speakers bureau: Bristol Myers Squibb

DOI: 10.1136/annrheumdis-2019-eular.3665

\section{FRI0272 RISK OF POTENTIAL GLUCOCORTICOID-RELATED ADVERSE EVENTS IN PATIENTS WITH GIANT CELL ARTERITIS: RESULTS FROM A US-BASED ELECTRONIC HEALTH RECORDS DATABASE}

Jennie H. Best ${ }^{1}$, Amanda M. Kong ${ }^{2}$, Oth Tran ${ }^{2}$, Margaret Michalska'. ' 'Genentech, Inc. South San Francisco, United States of America; ${ }^{2}$ IBM Watson Health, Ann Arbor, United States of America

Background: Oral glucocorticoids (OGC) have been the mainstay of treatment for giant cell arteritis (GCA). However, OGCs are associated with several adverse events (AEs).

Objectives: To estimate the risk of potential OGC-related AEs in patients with GCA.

Methods: This retrospective, observational cohort study utilized the 20082017 IBM Explorys Electronic Health Records database which includes lab values. Inclusion criteria included age $\geq 50$ years with $\geq 2$ GCA diagnoses $\geq 7$ days apart, 1 OGC prescription within 6 months of the first GCA diagnosis (index date = date of first OGC prescription) followed by a second OGC prescription, no other autoimmune disease requiring high-dose OGCs, no exposure to anti-tumor necrosis factor or anti-interleukin-6 therapies, $>1$ C-reactive protein (CRP)/erythrocyte sedimentation rate (ESR) lab test and 12 months of data available pre- and post-index. Potential AEs assessed during the 12 months post-index were descriptively summarized across cohorts of patients based on quartiles (Q) of mean daily dose of OGCs measured over 6 months post-index among this patient sample (Q1: $\geq 1.00$ to $\leq 13.75 \mathrm{mg}$; Q2: $>13.75$ to $\leq 25.00$ $\mathrm{mg} ; \mathrm{Q} 3:>25.00$ to $\leq 40.00 \mathrm{mg} ; \mathrm{Q} 4:>40.00 \mathrm{mg}$ ). Potential AEs included type 2 diabetes (T2D) diagnosis, hemoglobin A1c (HbA1c), blood glucose level, serious infections, cataracts, gastrointestinal bleeding or ulcer and increases in body mass index (BMI). Actual OGC use by patient could not be confirmed and is a limitation of this study.

Results: Mean age of the 785 eligible patients was 76 years (SD 9); $70 \%$ were female. Mean Deyo Charlson Comorbidity Index score at baseline was 1.57 (SD 2.01). The most common baseline comorbid conditions were cerebrovascular disease, diabetes, chronic pulmonary disease, and renal disease. Mean daily OGC dose was $28.9 \mathrm{mg}$ during the first 6 months post-index. Mean (SD) CRP and ESR during the 12-month follow-up was 5.1 (13.6) and 26.5 (20.7), respectively. The proportion of patients with newly diagnosed T2D or with $\mathrm{HbA} 1 \mathrm{C}>7.5$ during the 12 month follow-up ranged from $7.5 \%$ to $24.5 \%$ from OGC daily dose Q1 to Q4 cohorts. The proportion of patients with glucose $\geq 200 \mathrm{mg} / \mathrm{dL}$ ranged from $7.5 \%$ to $15.0 \%$ from Q1 to Q4. Serious infections ranged from $16.8 \%$ to $24.8 \%$ from Q1 to Q4 and cataract ranged from $12.0 \%$ to $21.7 \%$ from Q1 to Q4. The proportions of patients with gastrointestinal bleed/ulcer ranged from $6.0 \%$ in Q1 to $11.8 \%$ in Q4. An increase in BMl of 5 ranged from $4.1 \%$ to $6.4 \%$ from Q1 to Q4.

Conclusion: In patients with GCA, potential OGC-related AEs increased with increased daily OGC dose. This highlights the need for effective therapies that reduce the exposure and potential risk of OGCs.

Acknowledgement: This work was supported by funding from Genentech, Inc

Disclosure of Interests: Jennie H. Best Shareholder of: Genentech, Employee of: Genentech, Amanda M. Kong Employee of: IBM Watson Health, Oth Tran Employee of: IBM Watson Health, Margaret Michalska Employee of: Genentech, Inc.

DOI: 10.1136/annrheumdis-2019-eular.1657 